\title{
TERMINAL PLEISTOCENE LITHIC TECHNOLOGY AND USE OF SPACE IN CENTRAL CHILE*
}

\author{
TECNOLOGÍA LÍTICA Y USO DEL ESPACIO DEL PLEISTOCENO \\ TERMINAL EN EL CENTRO DE CHILE
}

\author{
César Méndez ${ }^{1}$ and Donald Jackson ${ }^{1}$
}

\begin{abstract}
We synthesize lithic evidence from terminal Pleistocene sites in Central Chile ( 31-34 $\mathrm{S})$. Quebrada Santa Julia, Valiente, Taguatagua 1 and Taguatagua 2 sites show diverse assemblages, which are not fully understood by a traditional typological approach. This diversity can be better explained due to variations in discard rates, raw material availability, and site function. This approach allows the consideration of early hunter-gatherer occupations as integrated segments of a two-stage evolving use of space/mobility system.
\end{abstract}

Keywords: Lithic technology, use of space, late Pleistocene, Central Chile.

Sintetizamos la evidencia lítica de los sitios del Pleistoceno terminal en el centro de Chile ( 31-34º S). Los sitios Quebrada Santa Julia, Valiente, Taguatagua 1 y Taguatagua 2 muestran conjuntos diversos, los que no son completamente entendidos a partir de una aproximación tipológica tradicional. Esta diversidad puede ser mejor explicada como resultado de variaciones en los ritmos de descarte, disponibilidad de materias primas y función de sitio. Esta aproximación permite considerar a las ocupaciones de los cazadores recolectores tempranos como segmentos integrados de un sistema de uso de espacio y movilidad de dos fases en evolución. Palabras claves: tecnología lítica, uso del espacio, Pleistoceno tardío, Centro de Chile.

Traditional typological approaches in the study of lithic technology are based on ideal forms of selected highly-formal tool classes. These approaches have been recurrently applied in the archaeological study of the initial peopling of South America (Bueno 2010; Kaulicke 1994). Inductively defined tool types coupled with contextual information and faunal inventories became static references for the comprehension of early occupations framed within the dominant theoretical Culture History approach. Given the fact that lithic artifacts are especially frequent in early sites, this approach grew strong. However it has limited explanatory capacity because:

(1) Most assemblages are largely composed of lithic debitage and informal tools.

(2) The presence of formal tools is dependent on raw material availability (Andrefsky 1998).

(3) Relying mainly on ideal designs limits the understanding of technological variability, especially if tool use-lives, maintenance and re-working are considered.

We believe that focusing on particular tool types is restrictive for a global comprehension of early human occupations in South America. This has been the case with "fishtail" projectile points. A well-known chronological marker since their early discovery in association with megafauna (Bird 1993), "fishtail" projectile points have been recurrently seen as the most recognizable tool type for the early settlers of South America (Politis 1991). In central Chile, lithic technology from terminal Pleistocene sites excavated over the last 45 years has been recently studied following a detailed methodology (Méndez 2014). By acknowledging the issues mentioned earlier, we integrate selective attributes of the lithic evidence and contextual information in order to raise some ideas regarding site function and use of space by

* This article was originally presented at the "Early Lithic Technologies: Beyond Regional Projectile Point Typologies" Symposium at the 77th SAA Meeting Memphis, Tennessee, April 2012. Guest editor Kurt Rademaker coordinated the peer-review process following the journal's editing policies.

1 Departamento de Antropología, Facultad de Ciencias Sociales, Universidad de Chile, Ignacio Carrera Pinto 1045, Ñuñoa, Santiago,Chile.cmendezm@uchile.cl; djackson@uchile.cl 
the earliest inhabitants of the region. In this paper we (1) consider entire assemblages, not just formal tools, (2) discuss the regional availability of lithic raw materials in order to understand technological decision-making, (3) incorporate tool use-lives as a dimension informative of the characteristics of site abandonment, and (4) focus on tool class diversity.

For the aim of this paper, we selected sites with recognizable radiocarbon-dated occupations framed within the latest Pleistocene $(14,000-11,500 \mathrm{cal} \mathrm{BP})$ yielding lithic assemblages and whose contextual information was complete enough to discuss aspects related to their functional variability. Throughout the paper, all ages are discussed in calendar years BP (cal BP) (2-sigma range) and were calibrated with the OxCal 4.2 program (Bronk Ramsey 2009) using the ShCal 13 curve (Hogg et al. 2013).

\section{Study Area and Paleoenvironments}

The study area extends from $31^{\circ} 50^{\prime}$ to $34^{\circ} 30^{\prime} \mathrm{S}$ (Figure 1) and includes the southernmost area of the Northern Semiarid Zone and the Mediterranean Zone of Chile (Romero 1985). The area is characterized by dry summers and low winter precipitation, in a system controlled by the Subtropical Anticyclone of the South Pacific and its latitudinal inter-annual migration (Van Heusen 1967). Sclerophyll shrublands grow in the north of this area and sclerophyll forests to the south (Luebert and Pliscoff 2006).

Prevailing conditions during the first entry of humans to the area during the terminal Pleistocene were more humid than the current climate, although framed in a general drying process that began after the Last Glacial Maximum, as recorded by both terrestrial and offshore paleoclimatic archives (Kim et al. 2002; Lamy et al. 1999; Valero-Garcés et al. 2005). The path to modern conditions, however, was not a progressive unidirectional process, but rather proceeded in stages and with reversals (Kim et al. 2002; Maldonado et al. 2010). Between 13,500 and $11,500 \mathrm{cal} \mathrm{BP}$, central Chile presented wetter-than-present conditions that allowed the growth of Nothofagus dombeyi type forests (Valero-Garcés et al. 2005) coupled with strong sea-surface-temperature alternations (Kim et al. 2002). Under these conditions, vegetation showed a greater diversity of tree species (Nothofagus), which disappeared from central Chile at $11,800 \mathrm{cal}$ BP (Valero-Garcés et al. 2005), migrating to their current position south of $\sim 36^{\circ} \mathrm{S}$ (Luebert and Pliscoff
2006). Faunas during the late Pleistocene were also more diverse than at present, with large and medium size mammals abounding (Casamiquela 1976). The shift towards drier Holocene conditions has been recorded at 11,200 cal BP in the Northern Semiarid Zone (Maldonado et al. 2010).

\section{Methods and Sampling}

Survey methods included both an assessment for quality and availability of potential lithic resources and archaeological surface sampling. Surveys were directed towards areas where previously known terminal Pleistocene lithic resources were supposedly procured with the aim of characterizing early stages in lithic production in key areas. Within-site sampling techniques in this paper vary greatly because the different locations we discuss were excavated over a large time span. However, all excavations included careful recovery methods, awareness for spatial associations and human-made features, piece plotting and sampling for bones, organic remains, and paleoenvironmental indicators. Particularly, excavations at Quebrada Santa Julia and at Valiente followed a $100 \%$ artifact recovery strategy, including piece-plotting of all artifacts $\geq 5 \mathrm{~mm}$ in maximum size and water sieving with $2 \mathrm{~mm}$ mesh size in the former and dry screening with $2.5 \mathrm{~mm}$ mesh size in the case of the latter.

Quantifications throughout this paper discriminated between valid counts and fragments, considering all complete pieces and those bearing platform remnants within the former group (Andrefsky 1998). Raw material identification considered: (1) within-assemblage empirical identification of rock types, (2) knapping quality grouping, and (3) raw material grouping based on regional availability. Site function was assessed by considering tool-classes and whether there were sufficient data to defend in situ tool production. Finally, tool design and use-lives were interpreted on the basis of design analysis, which included technical drawings considering technological attributes and by describing changes in artifact morphology during use-life. Assigning particular tool-classes was crosschecked with functional analyses.

\section{Terminal Pleistocene Sites in Central Chile}

During 1967 a systematic research project initiated stratigraphic excavations at the Taguatagua 1 


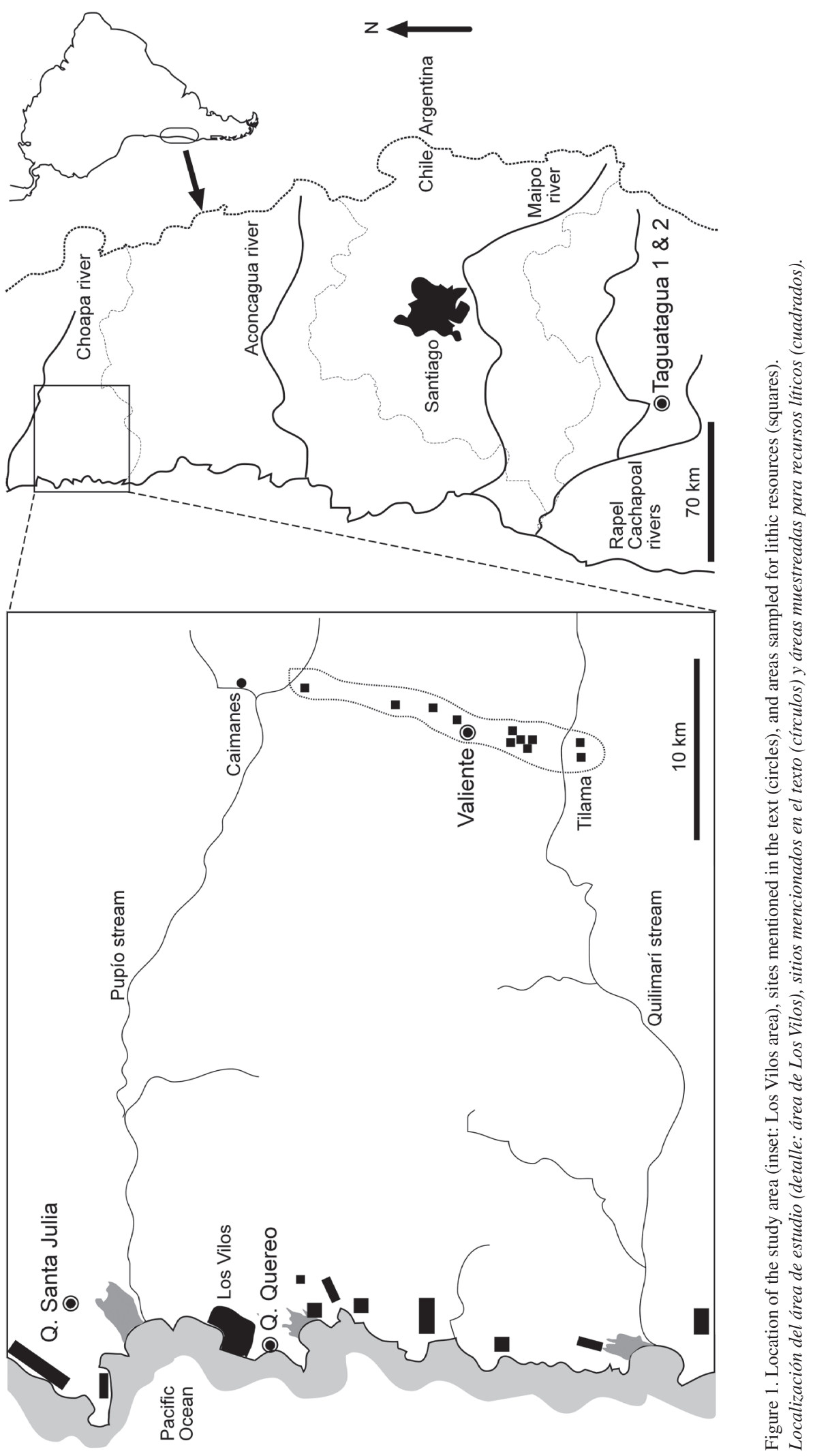




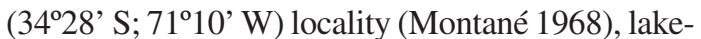
basin setting in Mediterranean Chile, known for its noticeable Quaternary mammalian paleontological findings. The stratigraphy at the site shows a succession of lacustrine deposits spanning from the Pleistocene until the late XIX century (Varela 1976), the moment when the artificial drainage of the lake occurred. Excavations located a context represented by one occupational level, with dates ranging from $13,940-12,670$ to $13,410-12,180 \mathrm{cal}$ $\mathrm{BP}$ and a confident averaged date of 13,12012,720 cal BP $(\mathrm{n}=4)$ (Méndez 2013). Abundant bones of mastodon, native horse and deer are among the most conspicuous remains, suggesting human intervention, especially on the horse, as shown by cut marks (Jackson et al. 2011). Two independent field seasons, at first by J. Montané (1968), and later by L. Núñez (Núñez et al. 1994), identified a primary context located at a lake-edge setting where human-made artifacts were unambiguously identified in association with the extinct mammal evidence.

Some 700 meters south, off-site excavations carried out by L. Núñez managed to identify a second site. The context at Taguatagua 2 represents one occupational level, deposited within a paleosol with dates ranging from $12,250-11,230$ to 11,750 $10,890 \mathrm{cal} \mathrm{BP}$, with a confident averaged date of 11,720-11,210 cal BP $(\mathrm{n}=2)$ (Méndez 2013). The occupation took place within a process of lake-basin contraction framed in a climatic drying trend (Valero-Garcés et al. 2005). The context is a primary deposition that occurred most probably at the edge of the lake, where several hunting and butchering episodes took place, as suggested by the ordered piles of bones (Núñez et al. 1994) of at least 10 individuals of Cuvieronius hyodon (Jackson et al. 2011). There is less evidence indicative of the consumption of other taxa such as native horse or deer; however the withdrawal of mastodon skeletal parts is suggestive of transport of selected portions to other integrated campsites (Jackson et al. 2011).

Quebrada Santa Julia is a site is located $3.5 \mathrm{~km}$ from the coastal margin ( $31^{\circ} 50^{\prime} \mathrm{S} ; 7^{\circ} 29^{\prime} \mathrm{W}$ ), $9 \mathrm{~km}$ northeast from Los Vilos town, within the southernmost limit of the northern Semiarid Zone of Chile. Along a small ravine, an exposed sedimentary sequence shows 38 sand and sandy/ clayey intercalated strata, in which layer 37 is a fine-grained organic black peat yielding a late Pleistocene human occupation (Jackson et al. 2007). The rest of the depositional sequence is mainly culturally sterile. Three field seasons (2004-2006) completed $27 \mathrm{~m}^{2}$ of excavations that revealed an undisturbed primary context, only 5 to $8 \mathrm{~cm}$ thick. The context represents one occupational level, with dates ranging from $13,070-12,740$ to 12,970 $12,680 \mathrm{cal} \mathrm{BP}$ and a confident averaged date of 12,990-12,730 cal BP $(\mathrm{n}=3)$ (Méndez 2013). Paleoclimatic and geomorphologic reconstructions suggest the area constituted a small lake basin during the late Pleistocene (Maldonado et al. 2010; Ortega et al. 2012). At the site, hunter-gatherer activities included the processing/consumption of at least one native horse and possibly an edentate in proximity to the hunting area (Jackson et al. 2011).

Excavations at Quebrada Santa Julia signaled high-quality translucent quartz crystal as one of the most significant raw materials used at the site. The nearest occurrence of quartz in the region was previously mapped by Rivano and Sepulveda (1996) between the inland localities of Caimanes ( $31^{\circ} 56^{\text {' }}$ S) and Tilama $\left(32^{\circ} 05^{\prime} \mathrm{S}\right)$; both $\sim 35 \mathrm{~km}$ from the coast. We designed and conducted systematic surface surveys along the area linking these two localities (Méndez et al. 2010), and identified the Valiente (CT14) site (32 $\left.01^{\prime} \mathrm{S} ; 71^{\circ} 09^{\prime} \mathrm{W}\right)$. Immediately adjacent to a currently exploited quartz quarry, on a glacis slope near the contact with the alluvial terrace of a small intermittent ravine (El Naranjo), a small profile exposed abundant flakes and occasional bifacial pieces within a $90 \mathrm{~cm}$ deposit. Excavations comprising a total of $12 \mathrm{~m}^{2}$ have uncovered a significant lithic assemblage associated with small and infrequent charcoal particles and burned bone fragments. Though difficult, the identification of bones has only indicated artiodactyls and fox (Lycalopex sp.) (Jackson et al. 2011), most probably processed and burned during knapping activities. Two ${ }^{14} \mathrm{C}$ dates bracket the archaeological level between 11,600-11,240 and 12,700-12,560 cal BP, suggesting several localized redundant occupational episodes (Méndez and Jackson 2012).

\section{Terminal Pleistocene Lithic Assemblages in Central Chile}

\section{General aspects}

The lithic assemblages studied vary significantly. As expected at a quarry site with redundant occupations spanning 1300 calibrated years, Valiente yields the largest assemblage with a total of 10,250 
lithics. Quebrada Santa Julia comprises a 969 lithic artifact sample, the two excavations at Taguatagua 1 include a total of 88 artifacts, and the smallest assemblage is that of Taguatagua 2, yielding only 32 artifacts. These substantial quantitative differences represent the first level of variability between the sites under discussion. Because laboratory analyses have not been completed at Valiente, we include a general reference of this assemblage in order to comment on the occurrence of quartz crystal in a quarrying workshop context. However, it is important to mention that it includes not only the first stages in lithic procurement, but also debitage including biface fragments and bifacial thinning flakes. In an area of lithic procurement such as this, we would expect a high proportion of fractured artifacts due to the nature of early stages of lithic processing.

Table 1 shows the studied assemblage organized by lithic classes. Debitage sub-classification has been omitted for the purpose of discussing general trends. This table also presents the frequency of complete and fragmented artifacts in each assemblage. By producing a fracture index (complete/fractured), Quebrada Santa Julia (0.64) highly resembles the incidence of fracture in Taguatagua 2 (0.714), and they are both different from that in Taguatagua 1 (1.333).

\section{Raw materials}

Raw material uses vary according to regional availability. In order to assess raw material selectivity and use we focused on general provenance of the raw material groups by conducting surface surveys along key areas near the archaeological sites studied in the coast of Los Vilos (Galarce 2004) and between Caimanes and Tilama localities (Méndez et al. 2010), inland of this area (Figure 1). Our knowledge of raw material distribution in the Taguatagua basin is much more limited and consists only of spot surveys along the basin itself and on the Zamorano stream, 2-4 km from the Taguatagua sites. While our knowledge of raw material use at Quebrada Santa Julia/Valiente area is a combination of regional lithic resource distribution, dated lithic assemblages, and bibliographical references, at the Taguatagua area it is basically derived from the last two, and thus should be considered as preliminary.

At Taguatagua 1, a minimum of 21 specific rock types were observed (Table 2), with more than $64.8 \%$ of the sample falling within above-average knapping qualities. These comprise a total of seven raw material groups on the basis of geology, grain size and knapping quality. At Taguatagua 2 out of nine specific rock types deposited at the site, grouping allowed us to identify five raw material groups. At this site, $41.17 \%$ of the sample has above-average knapping qualities. At Quebrada Santa Julia detailed observations allowed us to quantify a minimum of 30 specific rock types at the context, with $37.24 \%$ of above-average knapping qualities. Grouping in this particular case also included refitting. From the eight groups defined for this assemblage, three stand out: locally available coarse-grained lutite, locally available mid-grained siliceous tuffs and rhyolites (located along coastal small-sized ravines), and exotic high-quality quartz crystal, available 35 to $40 \mathrm{~km}$ inland. This last raw material is the only significant rock type observed at the Valiente site, as it comprises $99.6 \%$ of the studied assemblage.

By comparing this information with that produced by surface sampling we can discuss lithic assemblages according to raw material provenance groups (Table 3). Because our knowledge of lithic distribution in the Taguatagua basin is limited, besides the "local" raw materials we included a "presumably local" category for all rocks similar in quality to other locally identified rocks and with conspicuous attributes, such as significant cortex proportion, which suggested pebbles were procured near the site. Finally, the distinction between provenance of raw materials is based on ethnographic information provided by Meltzer (1989), who differentiates between immediately available, local $(<40 \mathrm{~km})$, and exotic $(>40 \mathrm{~km})$ rocks.

Quebrada Santa Julia site shows immediate and local resources comprising 62.09\%; while nonlocal quartz crystal accounts for $37.91 \%$ of the cases. At Taguatagua 1, local and presumably local raw material groups sum up $53.7 \%$, while exotics are only $3.7 \%$. However, the $42.59 \%$ of raw material groups for which we were not able to suggest provenance consists of high quality lithic resources that have not been located before in the area near Taguatagua. At Taguatagua 2, presumably local raw materials account for $52.94 \%$, while rocks grouped under the exotic category are $29.41 \%$, with a lesser incidence of undetermined raw material provenance. Finally, at Valiente site, we can confidently attribute roughly $100 \%$ of the sample to immediately available rocks. 


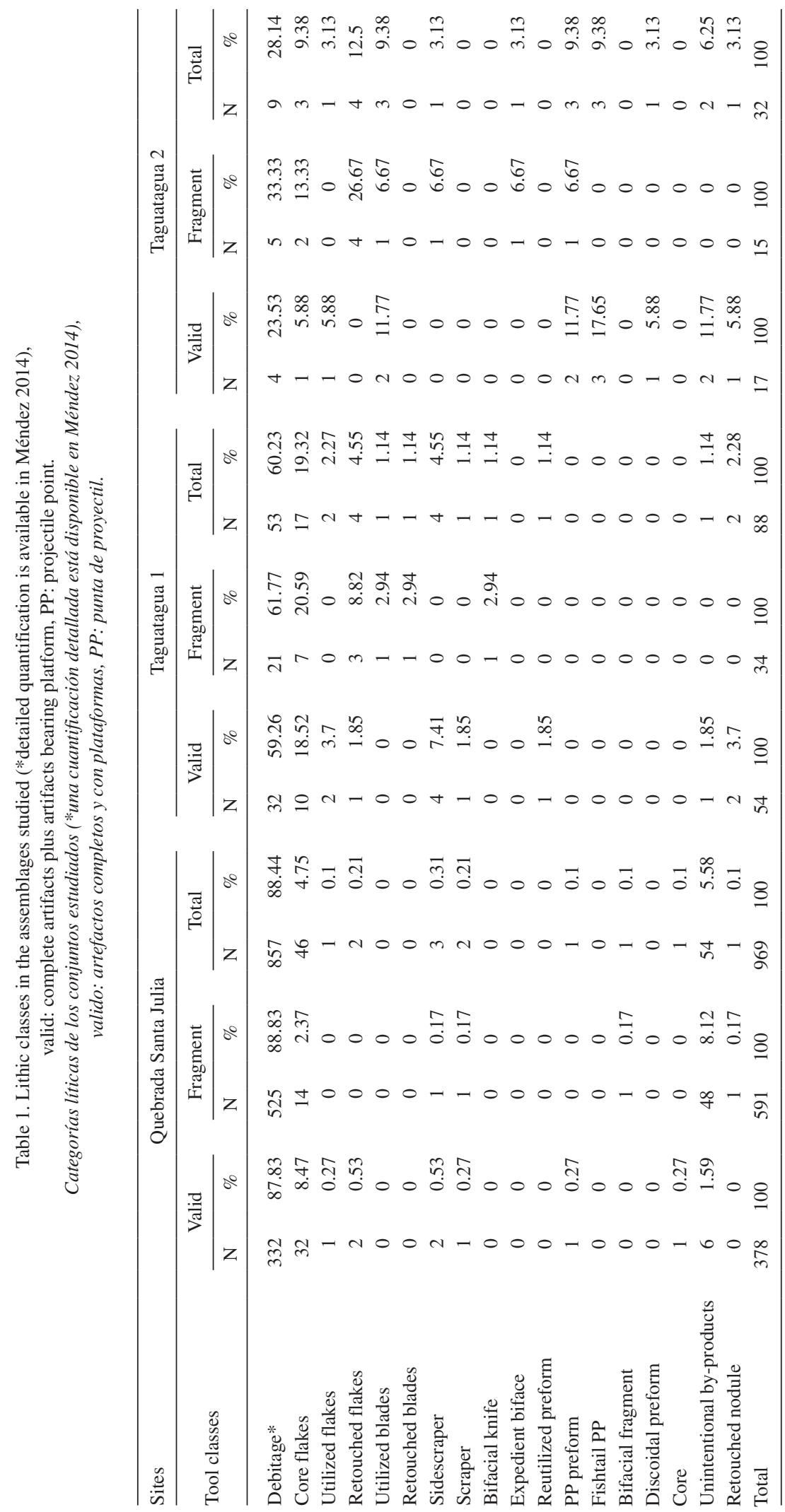


Table 2. Lithic raw materials and their knapping qualities in the sites studied, quantification includes only complete artifacts plus artifacts bearing platform.* Only fractured specimens.

Materias primas líticas y sus calidades para la talla en los sitios estudiados, la cuantificación incluye sólo artefactos completos y con plataformas. *Sólo especímenes fracturados.

\begin{tabular}{|c|c|c|c|c|c|c|c|c|c|c|c|c|c|}
\hline \multirow{2}{*}{\multicolumn{2}{|c|}{$\begin{array}{l}\text { Sites/rock types } \\
\mathrm{N}\end{array}$}} & \multicolumn{2}{|c|}{ Excellent } & \multicolumn{2}{|c|}{$\begin{array}{c}\text { Above } \\
\text { average }\end{array}$} & \multicolumn{2}{|c|}{ Average } & \multicolumn{2}{|c|}{ Regular } & \multicolumn{2}{|c|}{ Deficient } & \multicolumn{2}{|c|}{ Total } \\
\hline & & $\mathrm{N}$ & $\%$ & $\mathrm{~N}$ & $\%$ & $\mathrm{~N}$ & $\%$ & $\mathrm{~N}$ & $\%$ & $\mathrm{~N}$ & $\%$ & $\mathrm{~N}$ & $\%$ \\
\hline Quebrada & Quartz crystal $(\mathrm{N}=1)$ & 1 & 0.26 & 133 & 33.93 & 4 & 1.02 & 0 & 0 & 0 & 0 & 138 & 35.2 \\
\hline \multirow[t]{8}{*}{ Santa Julia } & Mid/fine grained rhyolithic tuff $(\mathrm{N}=1)$ & 1 & 0.26 & 1 & 0.26 & 27 & 6.89 & 14 & 3.57 & 0 & 0 & 43 & 10.97 \\
\hline & Fine grained lapilli tuff $(\mathrm{N}=1)$ & 0 & 0 & 3 & 0.77 & 26 & 6.63 & 37 & 9.44 & 0 & 0 & 66 & 16.83 \\
\hline & Tuffs and rhyolites ( $\mathrm{N}=17)$ & 1 & 0.26 & 4 & 1.02 & 14 & 3.57 & 21 & 5.36 & 8 & 2.04 & 48 & 12.24 \\
\hline & Lutites $(\mathrm{N}=3)$ & 0 & 0 & 1 & 0.26 & 0 & 0 & 5 & 1.28 & 63 & 16.07 & 69 & 17.6 \\
\hline & Coarse grained rocks $(\mathrm{N}=2)$ & 0 & 0 & 0 & 0 & 0 & 0 & 2 & 0.51 & 22 & 5.61 & 24 & 6.12 \\
\hline & Siliceous rocks $(\mathrm{N}=4)$ & 0 & 0 & 0 & 0 & 3 & 0.77 & 0 & 0 & 0 & 0 & 3 & 0.77 \\
\hline & Obsidian $(\mathrm{N}=1)$ & 1 & 0.26 & 0 & 0 & 0 & 0 & 0 & 0 & 0 & 0 & 1 & 0.26 \\
\hline & Total $(\mathrm{N}=30)$ & 4 & 1.02 & 142 & 36.22 & 74 & 18.88 & 79 & 20.15 & 93 & 23.72 & 392 & 100 \\
\hline \multirow[t]{8}{*}{ Taguatagua 1} & Basalts $(\mathrm{N}=3)$ & 2 & 3.7 & 15 & 27.78 & 1 & 1.85 & 0 & 0 & 0 & 0 & 18 & 33.33 \\
\hline & Non-siliceous rocks $(\mathrm{N}=2)$ & 0 & 0 & 0 & 0 & 4 & 7.41 & 1 & 1.85 & 0 & 0 & 5 & 9.26 \\
\hline & Mid grained siliceous rocks $(\mathrm{N}=2)$ & 0 & 0 & 1 & 1.85 & 2 & 3.7 & 0 & 0 & 0 & 0 & 3 & 5.56 \\
\hline & Fine grained siliceous rocks $(\mathrm{N}=8)$ & 5 & 9.26 & 10 & 18.52 & 5 & 9.26 & 0 & 0 & 0 & 0 & 20 & 37.04 \\
\hline & Obsidian $(\mathrm{N}=1)$ & 2 & 3.7 & 0 & 0 & 0 & 0 & 0 & 0 & 0 & 0 & 2 & 3.7 \\
\hline & Microgranodiorite $(\mathrm{N}=1)$ & 0 & 0 & 0 & 0 & 0 & 0 & 0 & 0 & 1 & 1.85 & 1 & 1.85 \\
\hline & Coarse grained rocks $(\mathrm{N}=4)$ & 0 & 0 & 0 & 0 & 0 & 0 & 2 & 3.7 & 3 & 5.56 & 5 & 9.26 \\
\hline & Total $(\mathrm{N}=21)$ & 9 & 16.67 & 26 & 48.15 & 12 & 22.22 & 3 & 5.56 & 4 & 7.41 & 54 & 100 \\
\hline \multirow[t]{6}{*}{ Taguatagua 2} & Non-siliceous rocks $(\mathrm{N}=2)$ & 0 & 0 & 2 & 11.76 & 0 & 0 & 0 & 0 & 0 & 0 & 2 & 11.76 \\
\hline & Mid grained siliceous rocks $(\mathrm{N}=4)$ & 1 & 5.88 & 1 & 5.88 & 1 & 5.88 & 0 & 0 & 0 & 0 & 3 & 17.65 \\
\hline & Fine grained siliceous rocks $(\mathrm{N}=1)^{*}$ & 0 & 0 & 0 & 0 & 0 & 0 & 0 & 0 & 0 & 0 & 0 & 0 \\
\hline & Quartz crystal $(\mathrm{N}=1)$ & 0 & 0 & 3 & 17.65 & 2 & 11.76 & 0 & 0 & 0 & 0 & 5 & 29.41 \\
\hline & Microgranodiorite $(\mathrm{N}=1)$ & 0 & 0 & 0 & 0 & 0 & 0 & 1 & 5.88 & 6 & 35.29 & 7 & 41.18 \\
\hline & Total $(\mathrm{N}=9)$ & 1 & 5.88 & 6 & 35.29 & 3 & 17.65 & 1 & 5.88 & 6 & 35.29 & 17 & 100 \\
\hline
\end{tabular}

\section{Tool production and tool diversity}

As Table 1 shows, tool classes vary between sites, especially when considering the differences between Quebrada Santa Julia and the others. Given the high frequency of lithic artifacts that comprise this sample, all comparisons are based on relative frequencies $(\%)$ and they are primarily based on complete artifacts.

An indicator of the importance of tool production was obtained by producing an index dividing all complete instruments by all complete core flakes, by-products and debitage. This index shows a rough view of the proportion that knapping activities had during the occupations. This comparison shows that Quebrada Santa Julia (0.022) and Taguatagua 1 (0.256), despite having different values, are both contexts where tool production occurred along with tool use/discard. On the other hand, on Taguatagua 2 (1.429), tool use/discard largely prevailed, and we can confidently suggest that most tools entered the site as fully functional instruments. The difference between Quebrada Santa Julia and Taguatagua 1 is that in the former, most tools were manufactured during the occupation, as has been shown by refits on quartz crystal and silicified tuff (Méndez 2014) and is suggested by the fact that there are no tools on raw materials other than the ones represented by debitage and vice versa. In the latter case debitage is not only infrequent, but it does not coincide with all of the variability of rocks from the tool group.

Regarding tool classes, a great deal of similarities can be identified between the Quebrada Santa Julia and Taguatagua 1 assemblages, which are consequently different than that of Taguatagua 2 . The former are mainly composed of informal designs, such as utilized and simple marginally retouched flakes. Also at these two sites, sidescrapers stand out as the single most frequent tool type, and scrapers 
Table 3. Lithic raw materials provenance in the sites studied, valid: complete artifacts plus artifacts bearing platform.

Procedencia de materias primas líticas en los sitios estudiados, valido: artefactos completos y con plataformas.

\begin{tabular}{|c|c|c|c|c|c|c|c|}
\hline \multirow{2}{*}{\multicolumn{2}{|c|}{$\begin{array}{l}\text { Sites/raw material provenance groups } \\
\mathrm{N}\end{array}$}} & \multicolumn{2}{|c|}{ Valid } & \multicolumn{2}{|c|}{ Fragments } & \multicolumn{2}{|c|}{ Total } \\
\hline & & $\mathrm{N}$ & $\%$ & $\mathrm{~N}$ & $\%$ & $\mathrm{~N}$ & $\%$ \\
\hline \multirow[t]{4}{*}{ Quebrada Santa Julia } & Immediate (lutite) & 69 & 18.96 & 123 & 21.58 & 192 & 20.56 \\
\hline & Local (tuffs \& rhyolites) & 157 & 43.13 & 194 & 34.04 & 351 & 37.58 \\
\hline & Quartz crystal (40 km) & 138 & 37.91 & 253 & 44.39 & 391 & 41.86 \\
\hline & Total & 364 & 100 & 570 & 100 & 934 & 100 \\
\hline \multirow[t]{5}{*}{ Taguatagua 1} & Local & 18 & 33.33 & 17 & 48.57 & 35 & 39.33 \\
\hline & Presumably local & 11 & 20.37 & 6 & 17.14 & 17 & 19.10 \\
\hline & Exotic & 2 & 3.70 & 0 & 0 & 2 & 2.25 \\
\hline & Not determined & 23 & 42.59 & 12 & 34.29 & 35 & 39.33 \\
\hline & Total & 54 & 100 & 35 & 100 & 89 & 100 \\
\hline \multirow{5}{*}{ Taguatagua 2} & Local & 0 & 0 & 0 & 0 & 0 & 0 \\
\hline & Presumably local & 9 & 52.94 & 6 & 40 & 15 & 46.88 \\
\hline & Exotic & 5 & 29.41 & 6 & 40 & 11 & 34.38 \\
\hline & Not determined & 3 & 17.65 & 3 & 20 & 6 & 18.75 \\
\hline & Total & 17 & 100 & 15 & 100 & 32 & 100 \\
\hline
\end{tabular}

are present, though not in high frequencies. In the latter case, besides informal utilized and retouched flakes, blades are an important tool-class. Bifacial artifacts are present at all three sites, though suggested uses are different. Finalized projectile points have only been identified at Taguatagua 2, while Quebrada Santa Julia shows fragments broken during manufacture, and Taguatagua 1 bifacial artifacts yield traces of use along the edges. Cores are infrequent at all sites; only one specimen was identified at Quebrada Santa Julia.

\section{Tool use-lives and designs}

For comparative purposes, tool use-lives have been divided into two broad categories: long-lived formal and short-lived expedient. This broad approach allows us to describe the general decisions in raw material economy, to identify choices between early discard or curation, and to link tool use-life groups to particular tool designs. Figures 2 and 3 show some selected tool designs which illustrate general trends in the designs. In the case of the former, we illustrate specimens gathered at the earlier sites, while in the latter we show tools recovered from Taguatagua 2 and Valiente.

Short-lived expedient tools identified in these assemblages are big flakes, either unretouched, or one-sided marginally retouched. Among the latter, the most conspicuous tool design is the regionally known "ultramarginal" retouched sidescrapers. These artifacts bear generally one-sided, extensive, and parallel-to-the-axis continuous pressure retouch, exclusively limited to the edge of the flake. It is likely that at least some utilized unretouched flakes constitute the blanks later transformed into this tool design. These kinds of flake instruments are generally manufactured on locally available raw materials and have short use-lives, generally limited to the activities carried out immediately, such as butchering and processing prey. One interesting exception is an ultramarginal sidescraper in Taguatagua 1 manufactured on an exotic variety of obsidian, bearing repeated retouch. Though the overall numbers of these assemblages may be considered small, sidescrapers are characteristic in Quebrada Santa Julia and Taguatagua 1, and present to a lesser extent in Taguatagua 2.

Long-lived formal tools are represented by bifacial and blade tools. While bifacial tools have been identified in all of the studied assemblages, blades are only characteristic of Taguatagua 2. Both groups of instruments are formalized and bear singular attributes that allow us to consider them as recognizable tool "types". These tool designs were elaborated with high-quality raw materials, which provided more suitable usable edges, and thus higher maintenance and transportability. On one hand, this relates to lower discard rates (especially when 
compared to the short-lived expedient group), which is characteristic of Taguatagua 2 where formal tools dominate the assemblage. Though Taguatagua 1 and Quebrada Santa Julia also yielded long-lived formal specimens, in these cases they have been recorded as fractured during manufacture and they are outnumbered by short-lived tools (Figure 4).
Among formal designs, the most recognizable are bifacial tools because of the amount of labor invested in their manufacture. This is the case of a fluted projectile point preform on quartz crystal identified in the Quebrada Santa Julia assemblage (Jackson et al. 2007), and the case of fishtail projectile points of the Taguatagua 2 (Núñez et al. 1994) and

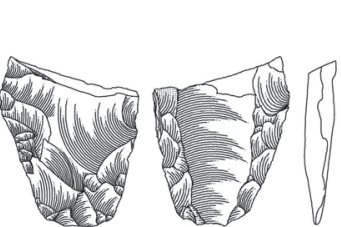

a.

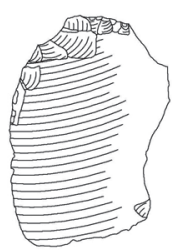

d.
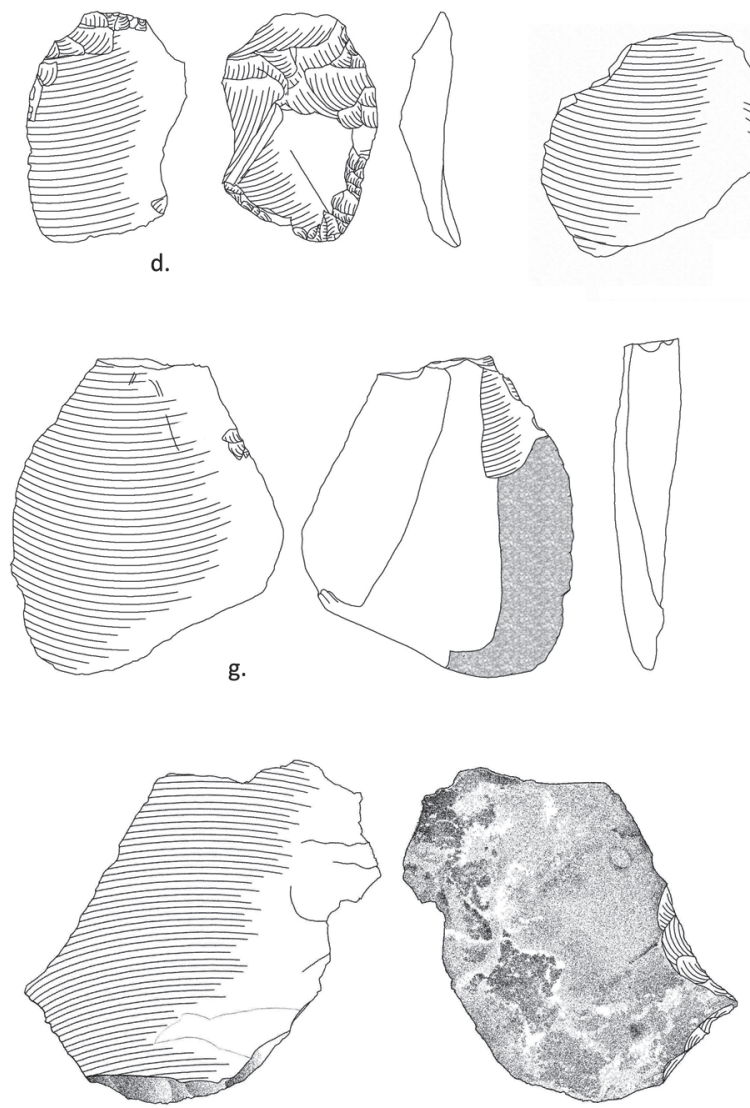

i.

b.
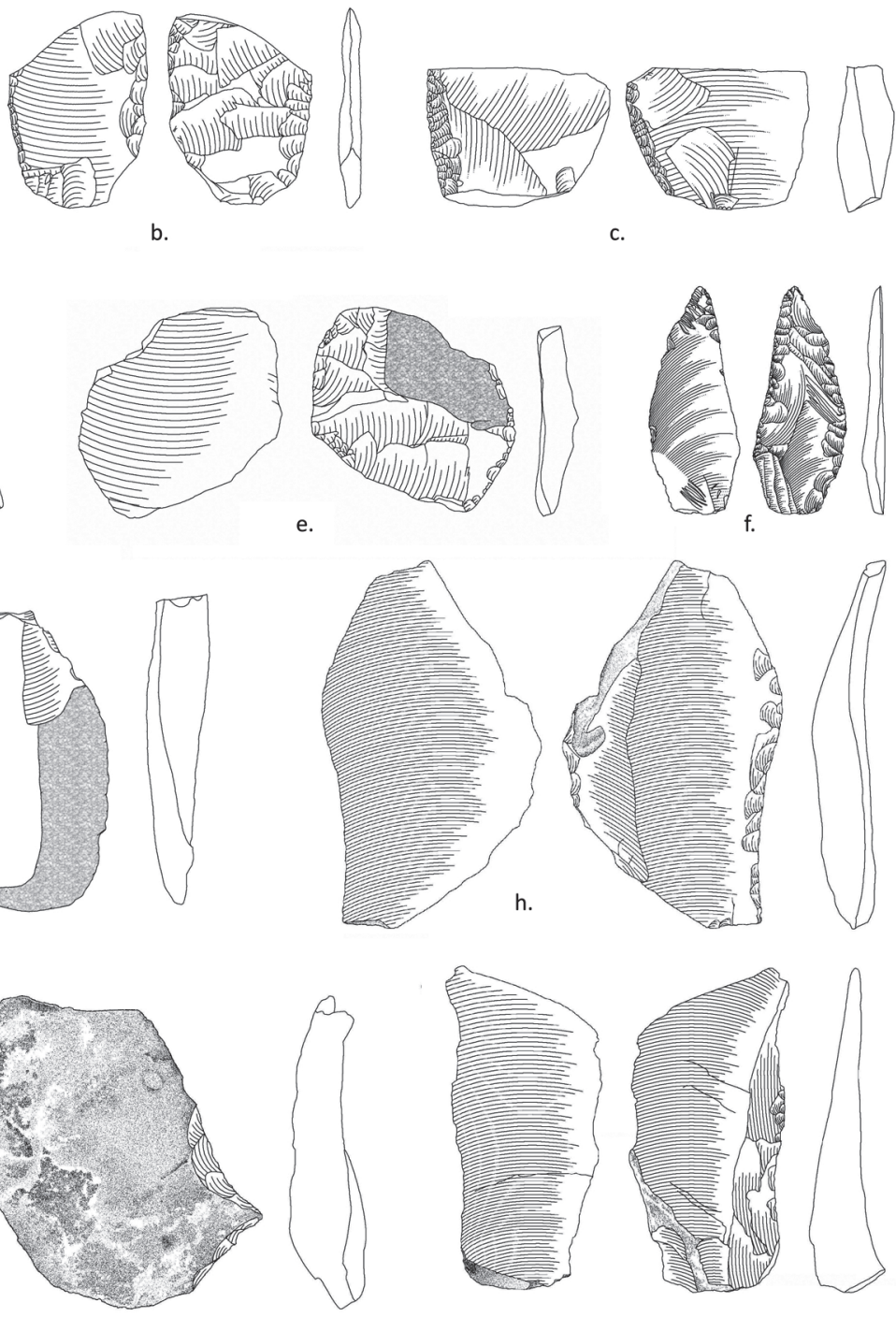

Figure 2. >12,700 cal BP lithic assemblages (Quebrada Santa Julia and Taguatagua 1 sites): a. fluted bifacial preform (quartz crystal), b. bifacial knife/preform (siliceous rock), c. ultramarginal sidescraper (obsidian), d. ultramarginal sidescraper (siliceous rock), e. retouched flake (quartz crystal), f. sidescraper (quartz crystal), g. utilized flake (basalt), h. ultramarginal sidescraper (rhyolithic tuff), i. retouched flake (tuff), j. lateral scraper (rhyolithic tuff); a., f., h.-j.: Quebrada Santa Julia; b.-e., g.: Taguatagua 1; scale is $1 \mathrm{~cm}$. Conjuntos líticos $>12.700$ cal a.p. (Quebrada Santa Julia y Taguatagua 1): a. preforma bifacial acanalada (cristal de cuarzo), b. preforma/cuchillo bifacial (roca silícea), c. raedera ultramarginal (obsidiana), d. raedera ultramarginal (roca silícea), e. lasca retocada (cristal de cuarzo), f. raedera (cristal de cuarzo), g. lasca usada (basalto), h. raedera ultramarginal (toba riolítica), i. lasca retocada (toba), j. raspador lateral (toba riolítica); a., f., h.-j.: Quebrada Santa Julia; b.-e., g.: Taguatagua 1; la escala es $1 \mathrm{~cm}$. 

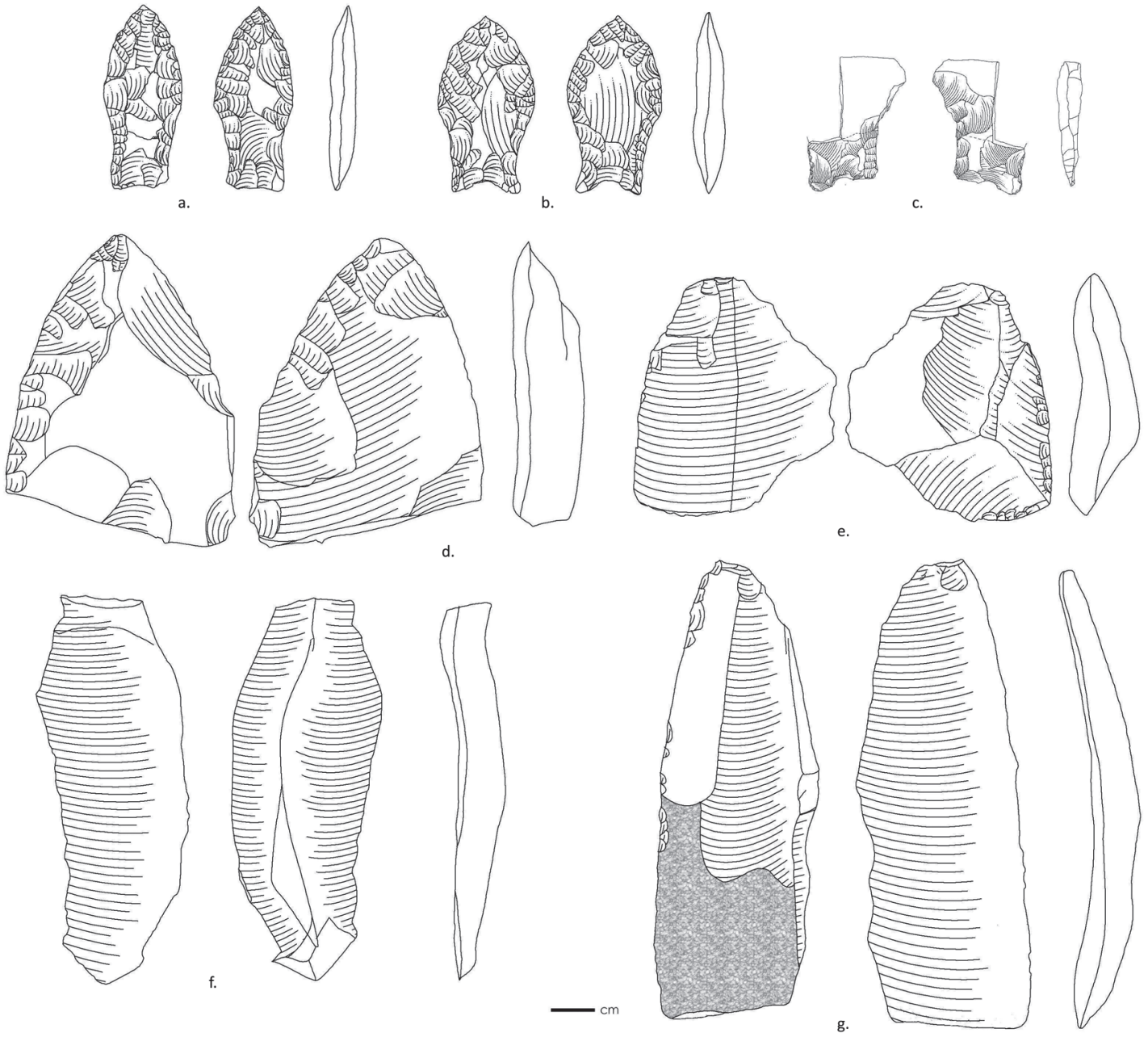

Figure 3. $<12,700 \mathrm{cal}$ BP lithic assemblages (Valiente and Taguatagua 2 sites): a.-b. Fishtail projectile points and c. preform (quartz crystal), d. ultramarginal sidescraper (siliceous rock), e. utilized flake (quartz crystal), f.-g. blades (f. siliceous rock and g. basalt); a.-b., d.-g.: Taguatagua 2; c. Valiente; scale is $1 \mathrm{~cm}$.

Conjuntos líticos $<12.700$ cal a.p. (Valiente y Taguatagua 2): a.-b. puntas de proyectil y c. preforma tipo cola de pescado (cristal de cuarzo), d. raedera ultramarginal (roca silícea), e. lasca usada (cristal de cuarzo), f.-g. láminas (f. roca silícea y g. basalto); a.-b., d.-g.: Taguatagua 2; c. Valiente; la escala es $1 \mathrm{~cm}$.

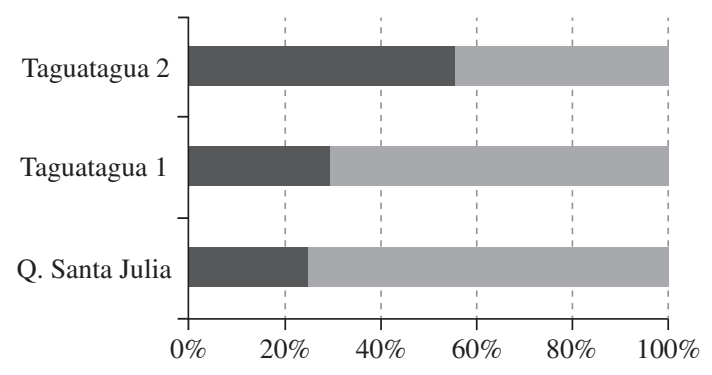

Long-lived fermal Short-lived espedient

Figure 4. Proportion of tool use-life groups at the sites studied. Proporción de grupos de herramientas de acuerdo a longitud de vida útil en los sitios estudiados. the Valiente site (Méndez et al. 2010). While the former was fractured during fluting (Méndez 2014), the latter type has been observed as ideal designs in Taguatagua 2, and as fractured items at Valiente.

\section{Discussion}

Studying the lithic assemblages of Taguatagua 1 and 2, Quebrada Santa Julia, and considering preliminary information gathered at the Valiente site has allowed us to build a comprehensive schema that aims to describe site function and use of space through the use of multiple attributes and not just relying on 
simple well-known tool types. Data produced by this study suggest that though there are many lithic raw materials of varying qualities present, high knapping quality rocks prevail at all sites during the terminal Pleistocene. Lithic catchment areas are highly dependent on regional raw material structure however, as we discuss below, some temporal trends affected the way in which lithic use evolved.

Tool/debitage ratio, used as a broad way to compare the significance of tool production, varied significantly between the sites. This suggests that there is variability in lithic manufacturing activities and thus in activity planning. The condition in which raw materials entered the sites (as finished tools or as blanks) also varied greatly according to regional availability; however, we were able to observe more similarities between Quebrada Santa Julia and Taguatagua 1, where flakes dominated, than with sites such as Valiente where quarrying activities involved chipping nodules or Taguatagua 2 where most artifacts entered as finished tools.

Quebrada Santa Julia, Taguatagua 1 and 2, and Valiente are sites representative of the initial human presence in central Chile and can be discussed as complimentary parts of an evolving system. Quebrada Santa Julia and Taguatagua 1, the earliest sites, represent single, very brief occupations where there is evidence of tool production, local and exotic raw materials in various qualities (though generally high qualities), and where the diversity of tool classes suggests several ongoing activities indicative of ephemeral residential camp occupations. Big flake tools, particularly sidescrapers, were likely useful for the butchering of big and mid-sized game, as has been reported as one of the main uses for this tool class (Hiscock et al. 2009; Rolland and Dibble 1990). This high raw material consuming task was appropriately accomplished with the use of short-lived, rapidly discarded tools manufactured with local rocks. These sites also include formal long-lived bifacial tools, like the fluted projectile preform recovered at Quebrada Santa Julia and the bifacial knife/ preform of Taguatagua 1. For these artifacts, as well as others, raw material selection included round trips to distant locations, the most likely scenario for the earliest toolstone acquisition. The case of quartz crystal from the Tilama/Caimanes source has provided a minimum observed distance of 35-40 km as an example of long-distance lithic procurement. Other unknown sources, as the one used in procuring obsidian probably involved even longer trips, as suggested by the current knowledge of available sources in the macroregion (Giesso et al. 2011). Though Valiente has not produced synchronic dates to those of Quebrada Santa Julia, quartz crystal at the latter is at least informative of the use of the area, possibly not at Valiente itself, but within the limits of the lithic source.

Although located in the same area as Taguatagua 1, averaged 2-sigma calibrated dates of Taguatagua 2 separate this occupation from the earlier site by at least 900 calendar years. The occupation shows a very limited assemblage of lithic tools and mostly mastodon remains (Núñez et al. 1994). The fact that bones were piled in order to maintain spatial organization is suggestive of multiple short-term occupations, probably separated by brief lapses of time. The high dominance of tools at the site along with the lack of debitage is indicative of use/discard of tools and no manufacturing activities. This further suggests the existence of other complementary sites in which tool production occurred. The evidence gathered at Valiente complements this assemblage because it exhibits abundant remains of lithic production associated with a very limited modern faunal assemblage. The context represents a series of superimposed brief occupations where quarrying activities took place, along with the production of bifacial tools. Given the fact that both Taguatagua 2 and Valiente share high-quality quartz crystal as the raw material for bifacial tools and that they also share fishtail projectile point design, it is reasonable to believe that they functioned within a common organizational system.

\section{Conclusions}

The preliminary scenario described above suggests during the first occupation of Central Chile $\left(\sim 31-34^{\circ} \mathrm{S}\right)$, when comparatively humid climatic conditions prevailed, hunter-gatherers in this region moved between locations through the use of short-term or ephemeral residential camps. Though these are as yet only represented by lake-shore settings, we know these peoples also recognized high-quality raw material sources and incorporated them early into their space/resource map. Tool production, use, and discard occurred within the same locations. The use of space changed sometime after 12,700 cal BP. Areas with privileged resource concentrations were periodically visited 
in short-span occupations, as suggested by highquality toolstone at Valiente and mastodon prey at Taguatagua 2. This led to a reorganization of tool production, use, and discard, which started occurring at different locations, separated both spatially and temporally. Changes in site planning and activities are informative of changes occurring in the organization of use of space and mobility. While hunter-gatherers remained highly mobile, they included more specifically designed camps, either focused on lithic acquisition and tool production, or on hunting, butchering prey, and retrieving selective skeletal parts. We are far from understanding if contemporary climatic changes had much influence on this spatial reorganization.

The schematic panorama described above needs further testing; however, this paper raises some hypotheses in order to continue with early technological research in central Chile. In this line, tool variability herein shown may be better explained by different discard rates, maintainability, and raw material availability, rather than typological attributes. Adopting an integrative perspective in the study of early lithic assemblages seems a more compelling and productive alternative than continuing within a normative typological approach.

Acknowledgements: funded by FONDECYT 1140824 grant. We acknowledge Kurt Rademaker, two anonymous reviewers, and the Chungara editorial staff for all the careful corrections and suggestions. All remaining errors are the authors' responsibility. We are indebted to Dr. Lautaro Núñez for his enormous support over the years.

\section{References Cited}

Andrefsky, W. 1998. Lithics. Macroscopic Approaches to Analysis. Cambridge University Press, Cambridge.

Bird, J. 1993. Viajes y Arqueología en Chile Austral. Ediciones de la Universidad de Magallanes, Punta Arenas.

Bronk Ramsey, C. 2009. Bayesian analysis of radiocarbon dates. Radiocarbon 51:337-360.

Bueno, L. 2010. Beyond typology: Looking for processes and diversity in the study of lithic technology in the Brazilian Amazon. Journal of World Prehistory 23:121-143.

Casamiquela, R. 1976. Los vertebrados fósiles de Tagua Tagua. Actas del Primer Congreso Geológico Chileno Volume I:88-102. Universidad de Chile, Santiago.

Galarce, P. 2004. Cazadores-Recolectores Tempranos en la Costa Sur del Semiárido: Aprovisionamiento y Procesamiento de Recursos Líticos. Degree thesis, Departamento de Antropología, Facultad de Ciencias Sociales, Universidad de Chile. Santiago.

Giesso, M., V. Durán, G.A. Neme, M.D. Glascock, V. Cortegoso, A.F. Gil, and L. Sanhueza 2011. A study of obsidian source usage in the Central Andes of Argentina and Chile. Archaeometry 53:1-21.

Hiscock, P., A. Turq, J.P. Faivre, and L. Bourguignon 2009. Quina procurement and tool production. In Lithic Materials and Paleolithic Societies, edited by B. Adams and B. Blades, pp. 232-246. Blackwell Publishing, Oxford.

Hogg, A., Q. Hua, P.G. Blackwell, M. Niu, C.E. Buck, T.P. Guilderson, T.J. Heaton, J.G. Palmer, P.J. Reimer, R.W. Reimer, C.S.M. Turney, S.R.H. Zimmerman 2013. SHCAL13 Southern Hemisphere Calibration, 0-50,000 years CAL BP. Radiocarbon 55(4): 1889-903.

Jackson, D., C. Méndez, L. Núñez, and D. Jackson 2011. Procesamiento de fauna extinta durante la transición PleistocenoHoloceno en el Centro-Norte de Chile. Boletín de Arqueología PUCP 15:315-336.
Jackson, D., C. Méndez, R. Seguel, A. Maldonado, and G. Vargas 2007. Initial occupation of the Pacific coast of Chile during Late Pleistocene times. Current Anthropology 48:725-731.

Kaulicke, P. 1994. Historia General del Perú: Los Orígenes. Editorial Brasa, Lima.

Kim, J., R. Schneider, D. Hebbeln, P. Muller, and G. Wefer 2002. Last deglacial sea-surface temperature evolution in the southeast Pacific compared to climate changes on the South American continent. Quaternary Science Reviews 21:2085-2097.

Lamy, F., D. Hebbeln, and G. Wefer 1999. High-resolution marine record of climatic change in mid-latitude Chile during the last 28,000 years based on terrigenous sediment parameters. Quaternary Research 51:83-93.

Luebert, F. and P. Pliscoff 2006. Sinopsis Bioclimática y Vegetacional de Chile. Editorial Universitaria, Santiago.

Maldonado, A., C. Méndez, P. Ugalde, D. Jackson, R. Seguel, and C. Latorre 2010. Early Holocene climate change and the first peopling of the semiarid coast of northern Chile. Journal of Quaternary Science 25:985-988.

Meltzer, D. 1989. Was stone exchanged among eastern North American Paleoindians? In Eastern Paleoindian Lithic Resource Use, edited by C. Ellis and J. Lothrop, pp. 11-39. Westview Press, Boulder.

Méndez, C. 2013. Terminal Pleistocene/Early Holocene ${ }^{14} \mathrm{C}$ dates from archaeological sites in Chile: discussing critical chronological issues for the initial peopling of the region. Quaternary International 301:60-73.

Méndez, C. 2014. Los Primeros Andinos. Tecnología Lítica de los Habitantes del Centro de Chile Trece Mil Años Atrás. Colección Estudios Andinos, Pontificia Universidad Católica del Perú, Lima. In press. 
Méndez C. and D. Jackson 2012. Procuring quartz crystal in Latest-Pleistocene/Early-Holocene sites in Northern Semiarid and Mediterranean-Central, Chile. In Southbound: Late Pleistocene Peopling of Latin America, edited by L. Miotti, M. Salemme, N. Flegenheimer, and T. Goebel, pp. 79-82. Center for the Study of the First Americans, College Station.

Méndez, C., D. Jackson, R. Seguel, and A. Nuevo Delaunay 2010. Early high quality lithic procurement in the Semiarid North of Chile. Current Research in the Pleistocene 27:19-21.

Montané, J. 1968. Paleo-indian remains from Laguna Taguatagua, Central Chile. Science 161:1137-1138.

Núñez, L., J. Varela, R. Casamiquela, V. Schiappacasse, H. Niemeyer, and C. Villagrán 1994. Cuenca de Taguatagua en Chile: El ambiente del Pleistoceno Superior y ocupaciones humanas. Revista Chilena de Historia Natural 67:503-519.

Ortega, C., G. Vargas, J. Rutllant, D. Jackson, and C. Méndez. 2012. Early Holocene major hydrological regime change along the semiarid western coast of South America. Quaternary Research 78:513-527.

Politis, G. 1991. Fishtail projectile points in the southern cone of South America: An overview. In Clovis: Origins and Adaptations, edited by R. Bonnichsen and K. Turnmire, pp. 287-301. Center for the Study of the First Americans, Oregon.

Rivano, S. and P. Sepúlveda 1996. Carta Geológica de Chile Hoja Illapel. SERNAGEOMIN, Santiago.

Rolland, N. and H. Dibble 1990. A new synthesis of Middle Paleolithic variability. American Antiquity 55:480-499.

Romero, H. 1985. Geografía de los Climas. Geografía de Chile, Tomo XI. Instituto Geográfico Militar, Santiago.

Valero-Garcés, B., B. Jenny, M. Rondanelli, A. Delgado-Huertas, S. Burns, H. Veit, and A. Moreno 2005. Palaeohydrology of Laguna de Tagua Tagua ( $34^{\circ} 30^{\prime} \mathrm{S}$ ) and moisture fluctuations in Central Chile for the last 46000 yr. Journal of Quaternary Science 20(7-8):625-641.

Van Heusen, C. 1967. Klimagliederung in Chile auf der Basis von Häufigkeitsverteilungen der Niederschlagssummen. Geographische Hefte 4:1-113.

Varela, J. 1976. Geología del Cuaternario de la Laguna de Taguatagua (Prov. de O'Higgins). Actas del I Congreso Geológico, pp. 81-112. Santiago. 
